\title{
My take on Media Aesthetics
}

\section{Liv Hausken}

My take on media aesthetics can briefly be set as an encounter between phenomenology, environmental aesthetics and philosophy of technology. Before I explain this position any further, I think it will be informative to retrace my route to media aesthetics.

The journey started in social anthropology and a comparative analysis of myths of salvation. What interested me were not so much the cultural similarities and differences between the myths from various parts of the world, but the way they were structured and how these structures influenced the tales that were told.

In the rearview mirror, then, it seems obvious that I would soon find myself studying textual theory and analysis at a department of comparative literature. This was in the late $1980 \mathrm{~s}$ and we were reading structuralism, post structuralism and deconstruction. These studies gave me the language I was looking for-and which anthropology couldn't offer. I was able to formulate my interest in narrative theory with a specific attention to narration or the way in which the stories were told. 
More generally, you may call it an interest in rhetoric, in the meaning of form and in ways of mediation. I then realized two things: First, all these theories seemed rooted in a theory of language, no matter how much they tried to establish a general concept of text; secondly, maybe not always in theory (e.g. Wolfgang Iser on how literature functions in human experience, or Algirdas Julien Greimas on the semantic logic of different articulations of human experience), but in practical analysis, there seemed to be little interest in the readers' acquaintance with reading as well as the importance of their prior knowledge of the world for the experience of the text.

I located this deficiency in various concepts that $\mathrm{I}$, in order to keep things simple, will place under 'the thesis of the semantic autonomy of the text,' be it the principle of immanence in French structuralism, the model of the organism and the pursuit of 'the figure in the carpet' in American New Criticism, or the three folded and boxed communication model in American narrative theory (Seymour Chatman). Roland Barthes was among those formulating these principles quite explicitly, in stressing, for example, that: "[...] the narrational code should be the final level attainable by our analysis, other than by going outside of the narrative-object, other, that is, than by transgressing the rule of immanence on which the analysis is based. Narration can only receive its meaning from the world which makes use of it: beyond the narrational level begins the world [...]. Just as linguistics stops at the sentence, so narrative analysis stops at discourse-from there it is necessary to shift to another semiotics".

This principle of immanence in French structuralism was heavily criticized during the 1980 s from perspectives of readerresponse theory, cultural studies and other sociologies, for not discussing the varieties of empirical readers and their various approaches to the text. This is not what I am after. Let me illustrate my criticism of these principles with two examples.

The filmmaker Wim Wenders started off as a painter. In a glowingly engaged lecture given to a workshop on narrative

1 Barthes (1966), "Introduction to the Structural Analysis of Narratives". 
techniques in $1988,{ }^{2}$ he explains his interest in moving from painting to film as follows: "The only thing I wanted to do, was to combine time and space; but from that moment I had to tell a story." The entire lecture demonstrates how much he hated that. My question is, why is it so difficult to avoid storytelling?

My second example, also related to narratives, is picked from the Danish poet and semiotician Per Aage Brandt and his essay "Hvad er en fortælling?" ("What is a Narrative," 1991), where he states: "We already 'know', what a narrative 'is' when we ask what a narrative is - otherwise we wouldn't know what we asked for. We 'just play' [or 'pretend'] that we don't know, to evoke proposals for decisions, which we can compare with what we think we know." "W What is it that we already know, and how can we come about to study it?

In the first example, and briefly put, Wenders is struggling against the audience's ability, or even the urge, to create a narrative. We may call this their narrative competence. The second example can be swiftly answered by the confident belief that we already know the cultural form called narrative. What we need is a theory of cultural competence, a knowledge of structures, or what the philosopher Paul Ricoeur would call prefigurations.

In the first part of his three-volume work on Time and Narrative (1983, English translation 1990), Ricoeur describes narrative understanding as a hermeneutic process of prefiguration, configuration and refiguration, where prefiguration covers the experiences from everyday life that are necessary to create and understand narratives, as well as a more specific narrative competence (familiarity with genres, etc.), configuration refers to the act of creating the actual plot, and refiguration suggests the way new stories are taken in as a new experience (or confirming an old experience, I would add on my own account). In his ar-

\footnotetext{
2 "Unmögliche Geschichten. Vortrag auf einem Kolloquium über Erzähltechniken", Danish translation, "Umulige historier".

3 Vi 'ved' allerede, hvad en fortælling 'er', når vi spørger, hvad en fortælling er - ellers ville vi ikke vide, hvad vi spurgte om. Vi 'leger bare', at vi ikke ved det, for at fremkalde forslag til bestemmelser, som vi kan sammenligne med, hvad vi mener at vide.
} 
ticle "Mimesis and Representation" (1981), Ricoeur presents a more general view on this hermeneutic circle (or spiral), insisting: "We must stop seeing the text as its own interior and life as exterior to it. Instead, we must accompany that structuring operation that begins in life, is invested in the text, then returns to life." Arguably, the various theses of the semantic autonomy of the text see "the text as its own interior and life as exterior to it". Following Ricoeur I will suggest, "we must accompany that structuring operation that begins in life, is invested in the text, then returns to life." For Ricoeur, the first step or dimension of this operation is explained with reference to phenomenology (Heidegger, in particular), the second concerning textual analysis (semiotics), and the third regarding application (Gadamer in particular, followed by the German aesthetics of reception, or Rezeptionsästhetik).

At this moment in time, if we now can go back to the tale of my journey toward media aesthetics, I had been at the department of media studies for about ten years, studying film and television. The problem with Ricoeur's Time and Narrative was not so much that his philosophy of narrative was developed with respect to verbal narratives (literature and historiography), rather, it didn't consider whether the technical apparatus mediating the story (in these cases presumably a book) would make a difference. I decided that my intellectual task in textual theory and analysis at a department of media studies had to be to call attention to whether the textual theories in question were neutral to medium or explicitly or implicitly dependent on one or a few specific media, and either way, make sure that all textual analysis performed and supervised was sensitive to the medium in which they were expressed. ${ }^{4}$ At this point, I was still doing textual theory and analysis.

The shift from media-sensitive textual theory and analysis to media aesthetics represented a shift from text to medium, from an interest in how the materiality of the text influenced the way the text made meaning, to an interest in the sensous qualities of

4 See for instance "Textual Theory and Blind Spots in Media Studies", in MarieLayre Ryan, Narrative Across Media, Nebraska Press. 
the experience. I needed a concept of sense and sensation that could be linked with a conception of knowledge. Since the term medium still was of importance to us, we came up with 'media aesthetics', first as a label, then as a notion to be developed.

My take on media aesthetics shares the concept of aesthetics with what has been referred to as environmental aesthetics, a relatively new sub-field of philosophical aesthetics that arose within what is called analytic aesthetics in the last third of the twentieth century (but which in my view doesn't have to be limited to a typically 'analytic' way of thinking).

Prior to its emergence, aesthetics (within the analytic tradition, and to a certain extent also elsewhere) was largely concerned with the philosophy of art. Environmental aesthetics originated as a reaction to this emphasis, pursuing instead the investigation of the aesthetic appreciation of natural environments. Since its early stages, the scope of environmental aesthetics has broadened to include not simply natural environments, but also human and human-influenced ones. At the same time, the field or approach has also come to include studies of that which falls within such environments, giving rise to what is called 'the aesthetics of everyday life' (see for instance Andrew Light and Jonathan Smith's book, The Aesthetics of Everyday Life, 2005, including contributions by crucial thinkers such as Arnold Berleant and Allen Carlson). Hence, the aesthetics of media aesthetics is not viewed as a philosophy of art. Rather, aesthetics is understood as a theory of culturally and historically embedded sensation and perception, conceptually developed from the original Greek sense of the term, as aisthesis or sense perception. The human perceiver is considered as embedded in the sociocultural environment and interacts with it continuously in an engaged and multisensory fashion (see Berleant 2005). This general model of aesthetic engagement is equally applicable to works of art and popular culture, and to the built and natural environment. Hence, aesthetics is here not confined to a particular kind of object, like art. Neither is it characterized by the specific properties of the object of inquiry. Rather, the perspective by which the objects are approached define it. The perspective incorporates the 
perceptual engagement described by Arnold Berleant as well as the influence of conceptual information and the ways in which conceptual knowledge may direct our perceptual scale and framing of the objects (see Carlson 2005). Aesthetics is seen as a critical reflection on cultural expressions, on technologies of the senses and on the experiences of everyday life.

Further, the term media is not primarily considered to refer to mass media or other social institutions and cultural formations, but rather to very specific technological arrangements that can be identified as such through the way they activate experiences with different media technologies. In this conception of media, particular objects, situations or phenomena are studied as complex expressions of mediation and are considered to be tools for the investigation of cultural preconditions and theoretical assumptions. The plurality of media is of interest not so much as a collection of narrowly defined technical entities or systems (cf Mitchell and Hansen, p. xiii), but rather as a reservoir of different technical premises, semiotic systems, modes, genres, and stylistic conventions, as well as of scholarly interests, academic discourses and kinds of knowledge. As N. Katherine Hayles and others have demonstrated, comparing media can make us recognize theoretical premises that are otherwise hard to see. Hayles refers to the field of comparative literature as she argues that: "Literary criticism and theory are shot through with unrecognized assumptions specific to print" (Hayles 2004 , p. 68). Years of interest in film adaptation among literary scholars has stimulated theoretical work on the distinctions between verbal language versus film language, but they have shown only a very modest concern for the conception of the material differences between the printed page and the projected image in the experience and interpretation of the work. As also noted by Hayles, "Only now, as the new medium of electronic textuality vibrantly asserts its presence, are these [unrecognized] assumptions [specific to print] clearly coming into view" (Hayles 2004, p. 68). The media aesthetic interest in the plurality of media critically discusses how some sensuous experiences seem neglected, while others are seen as pertinent in certain social and cultural situations. 
This may be characterised as a rhetorical and/or phenomenological interest in media aesthetics.

A rhetorical and phenomenological interest in media aesthetics should be seen historically in relation to a reorientation towards rhetoric in humanistic disciplines (particularly since the 1960s) and the renewed interest in the materiality of mediation in the 1990 s (most notably from Hans Ulrich Gumbrecht and Karl Ludwig Pfeiffer). Historically, Walter Benjamin's work has been of major importance here. Perspectives from what is often referred to as the Toronto School of Communication (Eric A. Havelock, Harold Innis, Edmund Snow Carpenter, Northrop Frye and Marshall McLuhan) have also been significant. Equally important is the revitalization of philosophical hermeneutics (Gadamer, Ricoeur) and phenomenology (Merleau-Ponty, Lyotard), particularly in studies of film and photography during the 1990s, and the growing interest in the philosophy of science and technology (N. Katherine Hayles, Don Ihde) in literature, media studies and humanistic informatics.

The philosophy of technology is a philosophical field dedicated to studying the nature of technology and its social effects. Considered under the rubric of the Greek term techne (art, or craft knowledge), the philosophy of technology goes to the very roots of Western philosophy. In the European context, Ernst Kapp is referred to as the founder of the philosophy of technology ("Grundlinien einer Philosophie der Technik", 1877). Five prominent 20 th century philosophers that directly address the effects of modern technology on humanity were John Dewey, Martin Heidegger, Herbert Marcuse, Günther Anders and Hannah Arendt. They all saw technology as central to modern life (even if they did so in very different ways). Of contemporary philosophers with an interest in technology, Don Ihde, Bruno Latour and maybe also Richard Sennet should be mentioned as particularly influencial on my take on media aesthetics.

So, finally, phenomenology: a philosophical tradition that has

\footnotetext{
5 Arguably, there is a complex relation between rhetoric and aesthetics through history. See for instance, John Poulakos' evocative discussion of the impact of rhetoric on the aesthetics of the 18 th century (Poulakos 2007).
} 
been mentioned several times already, but which should be explicated more specifically as to how it plays an important role in what I here present as a media aesthetic approach.

Certain aspects of contemporary phenomenology inspire this media aesthetic research strategy, most important of which is the phenomenological mode of description. As in contemporary phenomenology, a certain initial weighting occurs that has been characterized as radically empirical, in the sense that what is first dealt with is what is taken to be the experience. As Don Ihde pointed out in 1977 in his influential introductory book on phenomenological methodology, Experimental Phenomenology, "such a radical empirical beginning, while not lacking a definitional dimension, stands in contrast to other initial choices of theory [...]" (Ihde [1977] 1979, p. 30-31). Whereas, for example, "an axiomatic-constructive theory begins with a series of definitions and formal relations prior to investigation," phenomenology, in contrast, "begins with a kind of empirical observation directed at the whole field of possible experiential phenomena [...] Thus, its first methodological moves seek to circumvent certain kinds of predefinitions" (p. 31). The challenge is to pay attention to what seems to be taken for granted in a certain perception, that is, the sense of what is given. This does not imply that all givenness disappears, but rather, that the significance of the given is transformed.

So far, the media aesthetic research strategy that I am unfolding here goes hand in hand with contemporary phenomenology. However, in contrast to phenomenology, the purpose here is not to elicit structures or invariant constituents of a particular phenomenon, but rather to confront the culturally ignored or unthematized aspects of a particular phenomenon with theoretical conceptions in the field in question.

The second lesson from contemporary phenomenology relevant here is what has been termed the variational method: an imaginative comparison, a kind of thought experiment where one might think of one dimension of the object of study and then substitute some particular quality of that dimension with a different quality to see the effects of one on the other. This vari- 
ational method is inspired by the imaginative variations (or fantasy variations) of Edmund Husserl's phenomenology, critically adjusted and further developed by - among others - Don Ihde in his Experimental Phenomenology, and later in what he has coined postphenomenology (Ihde 1993, 2009). ${ }^{6}$ A somewhat idiosyncratic version of this variational method (as it is termed in contemporary phenomenology) can also be found in Roland Barthes' La Chambre Claire (1980), a phenomenologically inspired study of photography. Although Barthes does not exclusively vary the phenomenon in his own fantasy, he does describe concrete, empirical examples (mostly well-known photographs), in order to get closer to what has been termed the essence or invariants of photography as a phenomenon. This essence is the noema, what Barthes eventually ends up calling the "that-has-been." In other words, his study of photography here is not a comparative analysis of photographic images, nor is it a subjectivist analysis of reception. Rather, it is Barthes' version of what phenomenologists have called an analysis of intentionality, an analysis of the correlation of what is experienced with its mode of being experienced. An analysis from the point of view of media aesthetics may very well contribute to such an analysis of intentionality, but this is not its main purpose. The variational method suggested here is not so much to elicit structures or invariants of one particular phenomenon (see, for instance, Ihde 1979, p. 123), as it is to lodge a disturbing quality in what otherwise may appear to be a unified entity. By importing a series of disturbances, it is easier to see how the different variations make a difference.

Media aesthetic analysis is concerned with the question of how the medium matters. It never takes a particular medium as its point of departure. If it did, it would not see anything else. The media aesthetic analysis suggested here starts with the appearance of something identifiable as such, describing what appears. The description calls for distinctions and the concrete reflection calls for imaginative variations of the aspects or di-

\footnotetext{
6 Postphenomenology is a neologism of Don Ihde, referring to a modified, hybrid phenomenology combining insights from American pragmatism, Husserlian phenomenology and philosophy of technology (see Ihde 2009, p. 23).
} 
mensions that are of interest in the particular analysis. Since I have been particularly interested in how the medium makes a difference, the imaginative variations are normally chosen based on their capacity to make the function of the medium apparent in the case in question. The objective is to develop and practice an analytical sensitivity towards medial aspects that make a difference for the phenomenon or cultural expression in question. My point here is to stress the call for a more empirically based theoretical reflection in philosophies of media, and further to welcome the opportunity for challenging the researcher's theoretical apparatus in empirical research. Both theory and empirical analysis would benefit from taking this encounter seriously. The point is to develop a way of doing theory and analysis that can actually fulfill the ideal of an analysis that is sensitive to the nuances of media and that responds to the constant need for theoretical thinking and rethinking.

\section{REFERENCES}

Barthes, R. (1987 [1966]). "Introduction to the Structural Analysis of Narratives" in Image. Music. Text. Translated by S. Heath, Fontana Press: pp. 79-124. Original, "Introduction á l'analyse structurale des récits", first published in Communications, no. 8.

Barthes, Roland (1980). La chambre claire. Note sur la photographie. Cahiers du cinéma, Éditions de l'Étoile, Gallimard, Le Seuil, pp. 144-45. English translation, Camera Lucida, Vintage Edition, 1993.

Berleant, Arnold (2005). "Ideas for a Social Aesthetics", in Andrew Light and Jonathan Smith (eds): The Aesthetics of Everyday Life. Columbia University Press, pp. 23-38.

Brandt, Per Aage (1991). “Hvad er en fortælling?", Almen Semiotik nr. 3. Aarhus Universitetsforlag, pp. 67-84.

Carlson, Allen (2005). "What is the Correct Curriculum for Landscape", in Andrew Light and Jonathan Smith (eds): The Aesthetics of Everyday Life. Columbia University Press, pp. 92-108. 
Hayles, N. Katherine (2004). "Print Is Flat, Code Is Deep: The Importance of Media-Specific Analysis", in Poetics Today, 25:1, pp. 67-90. Inde, Don ([1977] 1979). Experimental Phenomenology. Putnam. Ihde, Don (1993). Postphenomenology: Essays in the Postmodern Context, Northwestern University Press.

Inde, Don (2009). Postphenomenology and Technoscience. The Peking University

Lectures, State University of New York Press.

Mitchell, W.J.T and Mark B.N. Hansen (2010). "Introduction", in W.J.T Mitchell and Mark B.N. Hansen (eds): Critical Terms for Media Studies. The University of Chicago Press.

Poulakos, John (2007). "From the Depths of Rhetoric: The Emergence of Aesthetics as a Discipline", in Philosophy and Rhetoric, Vol.40, No.4, pp. 335-352.

Ricoeur, Paul (1990). Time and Narrative, Volume 1. University of Chicago Press.

Ricoeur, Paul ([1981] 1991). "Mimesis and Representation”, in Mario J. Valdés (ed): Reflection and Imagination. A Ricoeur Reader. Harvester Wheatsheaf, pp. 137-155. Originally a lecture held in French in 1980, translated by Pellauer and published in Annals of Scholarship: Metastudies of the Humanities and Social Sciences 2, nr.3, pp. 15-32. Published in French in 1982 as "Mimesis et représentation", in Actes du XVIIIs Congrès des Sociétés de Philosophie de la langue francaise, Université des Sciences Humaines de Strasbourg, Strasbourg, pp. 51-63.

Wenders, Wim ([1988] 1991). "Umulige historier”, in BILLEDERNES LOGIK. Essays og samtaler. Rævens Sorte Bibliotek, pp.61-69. Translated by Helge Krarup, from "Unmögliche Geschichten. Vortrag auf einem Kolloquium über Erzähltechniken”, in Die Logik der Bilder. Essays und Gespräche, Verlag der Autoren, pp. 68-77. This lecture was held in French in Livorno, 1982, and translated into German by Marianne Karbe. 